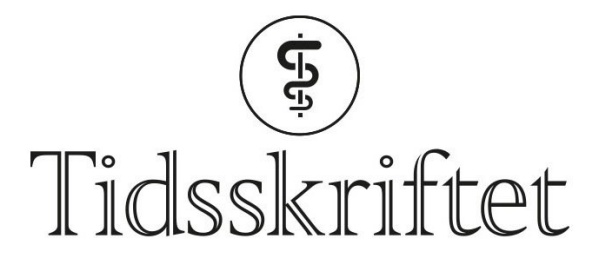

DEN NORSKE LEGEFORENING

\title{
Besvimelsen som forsvant
}

SPRÅKSPALTEN

ERLEND HEM

E-post: erlend.hem@medisin.uio.no

Erlend Hem er professor dr.med., fagsjef og redaktør for Tidsskriftets språkspalte.

Redaksjonen mottok for en stund siden et manuskript med ordet lipothymi. Ingen av oss kjente det fra før. Det var en interessant historie.

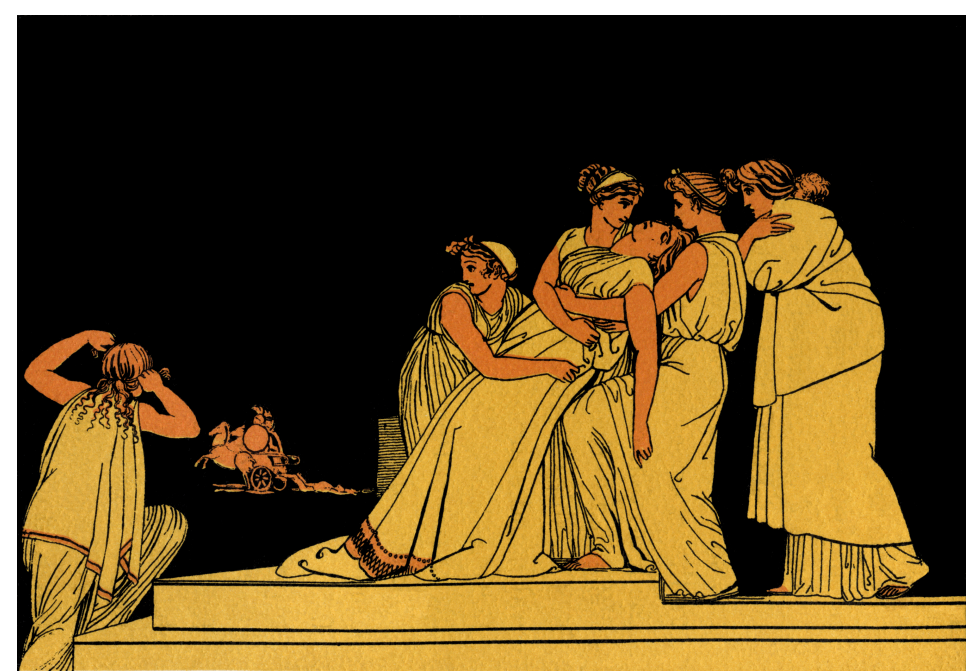

Illustrasjon: whitemay/iStock

Vi gjettet på at det hadde noe med det greske lipos, 'fett', å gjøre. Men i sammenhengen var det vanskelig å forstå, siden det handlet om en pasient som mistet bevisstheten. Etter hvert fant vi ordet i en gammel fremmedordbok, som kort og godt ga forklaringen 'besvimelse' (1).

Ettersom ingen moderne medisinske ordbøker var til hjelp, slo vi opp i et eldre engelsk verk. Også der sto det forklart som besvimelse, synkope, men i tillegg med opplysningen om det greske opphavet: leipein, 'mangle, forsvinne' + thymos, 'sinn' (2). Det kan også skrives leipothymia.

I Oxford English Dictionary er ordet merket med et kors - tegnet på at det er avgått ved døden (3). Et søk i PubMed gir kun 87 treff på lipothymia (10.2.2020). Det kan se ut til at ordet fortsatt brukes noe i dansk, slik det fremgår av en veiledning til danske leger fra helsemyndighetene: «Lipothymi, også kaldet synkope» (4).

Lipothymi står også i en eldre dansk medisinsk ordbok, med henvisning til kollaps (5), som gir en hærskare synonymer: apsychia, eklipsis, lipopsyki, lipotymi. Tiden har gått fra disse ordene. Fortsatt kan vi riktignok finne et enslig lipo-ord i ordbøkene som ikke har med fett å 
gjøre: lipofreni, 'mangelfull mental kapasitet' (6), men det brukes vel så sjelden i dag at det sikkert kan tas ut i neste utgave.

\section{Rik historie}

Men hvorfor forsvant ordet lipotymi fra medisinen? Vi vet ikke, men et oppslagsverk fra 1890-årene kan kanskje antyde et svar. Der står det at enkelte kolleger begrenset bruken av ordet "til första början af svimningen» - en findiagnostikk som neppe lenger er nyttig (7). En annen forklaring kan kanskje være besvimelsens rike kulturhistorie - man kunne sikkert trenge et omfattende vokabular for det, et behov som ikke lenger finnes. For som det står i en terapihåndbok fra midten av 18oo-tallet: «Størst Anlæg hos Fruentimmer, især hysteriske og svangre» (8).

Synkope er det vanligste fagordet nå for tiden. Det er gresk og betyr sammenslåing, av syn-, ‘sammen' og kope, 'slag' (9). Det har vært brukt i medisinen siden 1400-tallet (10).

\section{LITTERATUR:}

1. Lipothymi. I: Meyers fremmedordbog. https://meyersfremmedordbog.dk/ordbog?querylipothymi Lest 20.10.2018.

2. Taber’s cyclopedic medical dictionary. 6. utg. Philadelphia, PA: F.A. Davis, 1953: L-33.

3. Lipothymy, lipothymia. I: Oxford English Dictionary. https://www.oed.com/view/Entry/108858 Lest 20.10.2018.

4. Sundhedsstyrelsens vejledning om vurdering af helbredskrav til førere af motorkøretøjer. https://www.retsinformation.dk/Forms/Ro710.aspx?id=158670 Lest 20.10.2018.

5. Kollaps, lipot(h)ymi(a). I: Holm-Nielsen N, red. Klinisk ordbog. 12. utg. København: Høst, 1980:379, 415.

6. Lipofreni. I: Nylenna M, red. Medisinsk ordbok. https://www.ordnett.no/search?languageno\&phraselipofreni Lest 21.10.2018.

7. Svimning. I: Nordisk familjebok: konversationslexikon och realencyklopedie. Bd. 15: SockerTengström. Stockholm: Nordisk familjebok, 1891: 1110.

8. Bang OL. Haandbog i Therapien. Kjøbenhavn: Gyldendalske Boghandel, 1852: 33.

9. Synkope. I: Det norske akademis ordbok. https://www.naob.no/ordbok/synkope Lest 21.10.2018.

10. Syncope. I: Oxford English Dictionary. https://www.oed.com/view/Entry/196418 Lest 20.10.2018.

Publisert: 25. mai 2020. Tidsskr Nor Legeforen. DOI: 10.4045/tidsskr.20.0179

(C) Tidsskrift for Den norske legeforening 2020. Lastet ned fra tidsskriftet.no 